\title{
MODEL DAN STRATEGI PEMBELAJARAN
}

\section{LEARNING MODELS AND STRATEGIES}

\author{
Indriawati \\ e-mail: indriawati9090@gmail.com \\ STAI Az-Ziayadah Bekasi \\ Imam Buchori \\ e-mail: imambuchori@staip.ac.id \\ STAI Pelabuhanratu Sukabumi \\ Acip \\ e-mail: acip@staip.ac.id \\ STAI Pelabuhanratu Sukabumi \\ Sekarmaji Sirrulhaq \\ e-mail: sekarmaji@staip.ac.id \\ STAI Pelabuhanratu Sukabumi \\ Encep Solihutaufa \\ e-mail: hutaufaencep717@gmail.com \\ SMA Negeri 1 Simpenan
}

\begin{abstract}
Abstrak:
Upaya peningkatan kualitas pembelajaran diperlukan adanya perubahan-perubahan positif, untuk dapat mengelola pembelajaran secara efektif dan efisien seorang pendidik membutuhkan pengetahuan tentang model dan strategi pembelajaran. Oleh karena itu, dalam reformasi pembelajaran yang seharusnya dilakukan adalah bagaimana merubah pola kegiatan pembelajaran yang dapat mewujudkan suasana belajar dan proses pembelajaran terasa lebih menarik. Strategi pembelajaran yang berkualitas merupakan salah satu bentuk usaha untuk merubah pola model pembelajaran yang selama ini digunakan dalam proses pembelajaran. Keseluruhan kegiatan pendidik dan peserta didik dalam mewujudkan proses pembelajaran yang efektif terbentuk dalam paduan antara tahap-tahap kegiatan, metode, media pembelajaran serta waktu yang digunakan dalam kegiatan pembelajaran terangkum dalam strategi pembelajaran. Tujuan penelitian ini untuk mengetahui model dan strategi dalam proses pembelajaran. Penelitian ini menggunakan pendekatan kualitatif dengan jenis penelitian kepustakaan. Sumber data penelitian ini berasal dari buku, jurnal dan artikel ilmiah terkait model dan strategi pembelajaran. hasil penelitian menunjukan bahwa strategi pembelajaran yang tepat akan membina peserta didik untuk lebih kreatif dan mandiri. Pemilihan model dan strategi pembelajaran yang tepat akan dapat membina peserta didik ntuk dapat berpikir kreatif, mandiri dan adaptif terhadap berbagai situasi yang terjadi dang mungkin akan terjadi. Pendidik memikirkan dan mempersiapkan model dan strategi pembelajaran yang tepat agar peserta didik mampu menerima dan memproses informasi yang disampaikan oleh pendidik.
\end{abstract}


Kata kunci: Model, Strategi Pembelajaran

\begin{abstract}
:
Efforts to improve the quality of learning require positive changes, to be able to manage learning effectively and efficiently an educator requires knowledge of learning models and strategies. Therefore, in learning reform, what should be done is how to change the pattern of learning activities that can create a learning atmosphere and the learning process feels more interesting. Quality learning strategies are one form of effort to change the pattern of learning models that have been used in the learning process. All activities of educators and students in realizing an effective learning process are formed in a combination of the stages of activities, methods, learning media and the time used in learning activities are summarized in the learning strategy. The purpose of this study was to determine the models and strategies in the learning process. This study uses a qualitative approach to the type of library research. The data sources of this research come from books, journals and scientific articles related to learning models and strategies. The results of the study show that the right learning strategy will foster students to be more creative and independent. The selection of appropriate learning models and strategies will be able to foster students to be able to think creatively, independently and adaptively to various situations that occur and may occur. Educators think about and prepare appropriate learning models and strategies so that students are able to receive and process information conveyed by educators.
\end{abstract}

\title{
Keywords: model, learning strategy
}

Submitted: 09-12-2021 | Accepted: 20-12-2021 | Published: 26-12-2021

\section{PENDAHULUAN}

Tuntutan hasil belajar yang semakin tinggi dengan sistem pembelajaran yang masih terbilang biasa-biasa saja menjadi tugas para pendidik untuk mencari dan menemukan strategi pembelajaran yang lebih baik. Karena tidak adanya keseimbangan jika hasil belajar dari peserta didik yang diharapkan adanya peningkatan namun masih menggunakan metode pembelajaran yang tidak mendukung untu tercapainya hasil yang lebih berkualitas.

Sebagaimana diatur dalam PP 19 tahun 2005 pasal 19 ayat 1 tentang standar proses bahwa pembelajaran pada satuan pendidikan diselenggarakan secara interaktif, inspiratif, menyenangkan, menantang, memotivasi peserta didik untuk berpartisipasi aktif, serta memberikan ruang yang cukup bagi prakarsa, kreatifitas, dan kemandirian sesuai dengan bakat, minat dan perkembangan fisik serta psikologis anak.

Strategi pembelajaran menjadi hal yang penting untuk mengatasi ketidakseimbangan antara hasil dengan metode pembelajaran. Dengan adanya strategi pembelajaran yang tepat dapat menyesuaikan sistem pembelajaran yang digunakan oleh 
pendidik dalam menyampaikan materi pelajaran, sehingga target ketercapaian pembelajaran bisa dicapai. Strategi pembelajaran yang dibutuhkan saat ini yaitu strategi pembelajaran yang berpusat pada aktifitas peserta didik dalam suasana yang lebih menyenangkan. Sehingga potensi peserta didik dapat tergali dan teraktualisasikan dengan baik dan dapat menjadi pengalaman yang bisa digunakan untuk menghadapi tantangan masa depan.

Pentingnya meningkatkan strategi pembelajaran lebih baik lagi adalah sebagai solusi untuk mengatasi masalah pemberdayaan pendidikan dalam menyiapkan sumber daya manusia di masa depan. Salah satu penyebab permasalahan lulusan yang kurang memiliki kualitas yang diharapkan yaitu strategi pembelajaran yang diterapkan belum berorientasi pada memberdayakan peserta didik dan tugas pendidikan yang begitu berat banyak diserahkan kepada yang bukan ahlinya.

Para pendidik biasanya lebih banyak mendominasi dengan memberikan ice breaker agar suasana kelas menjadi lebih menyenangkan dan tidak membosankan. Cara seperti ini tidak sepenuhnya salah, akan tetapi substansi dari pembelajaran itu sendiri akan menjadi hilang sehingga akibat yang ditimbulkan akan fatal yaitu peserta didik tidak memiliki kompetensi yang diharapkan pendidik dan tujuan pembelajaran.

\section{METODE PENELITIAN}

Metode pendekatan yang digunakan dalam penelitian ini ialah menggunakan metode pendekatan kualitatif dengan jenis penelitian kepustakaan atau disebut dengan Library Research. Sumber data penelitian ini berasal dari buku, jurnal dan artikel ilmiah yang terkait dengan tantangan yang dihadapi oleh para pendidik tentang proses pembelajaran yang efektif. Analisa data dalam penelitian ini menggunakan teknologi Content Analysis, yaitu mengklasifikasi atau mengelompokkan data secara terpisah terkait pembahasan beberapa ide atau gagasan tokoh pendidikan, kemudian mendeskripsikan, mendiskusikan dan mengkritisinya. Selain itu, klasifikasikan data serupa dan analisis konten secara kritis untuk mendapatkan hasil yang spesifik dan memadai. 


\section{HASIL DAN PEMBAHASAN}

\section{Pengertian Model Pembelajaran}

Model pembelajaran meliputi suatu model pembelajaran yang luas dan menyuluruh. Konsep model pembelajaran lahir dan berkembang dari pakar psikologi dengan pendekatan dalam setting eksperimen yang dilakukan.

Ismail menyatakan istilah model pembelajaran mempunyai empat ciri khusus yang tidak dipunyai oleh strategi atau metode tertentu yaitu (Ismail, 2003, p. 13):

1. Rasional teoritik yang logis disusun oleh perancangnya,

2. Tujuan pembelajaran yang akan dicapai,

3. Tingkah laku mengajar yang diperlukan agar model tersebut dapat dilaksanakan secara berhasil dan tercapai.

4. Lingkungan belajar yang diperlukan agar tujuan pembelajaran itu dapat tercapai.

Pemilihan model pembelajaran yang tepat berguna untuk merancang suatu proses pembelajaran. Sebagaimana dikemukakan oleh Bruce Weil dalam Hamruni (Hamruni, 2011), ada tiga prinsip penting dalam proses pembelajaran. Pertama, proses adalah usaha kreasi lingkungan yang dapat membentuk atau mengubah struktur kognitif peserta didik, yang dimaksudkan untuk memberikan pengalaman belajar. Kedua, berhubungan dengan tipe-tipe pengetahuan yang harus dipelajari yaitu pengetahuan fisis (jasmani), sosial, dan logika. Ketiga, dalam proses pembelajaran harus melibatkan peran lingkungan sosial. Melalui pergaulan dan hubungan sosial pesrta didik akan belajar lebih efektif dibandingkan dengan belajar yang menjauhkan dari hubungan sosial. Karena dari hubungan sosial tersebut mereka berinteraksi dan berkomunikasi, berbagi pengalaman dan lain sebagainya, yang memungkinkan mereka berkembang secara wajar.

Jika model pembelajaran yang dipilih dan digunakan dalam proses pembelajaran sesuai dan tepat, maka pembelajaran akan menjadi efektif. Pembelajaran efektif merupakan pembelajaran yang menghasilkan belajar yang bermanfaat dan terfokus pada peserta didik melalui penggunaan prosedur yang tepat salah satunya adalah dalam pemilihan model pembelajaran, (Miarso, 2005, p. 536). 


\section{Pengertian Strategi Pembelajaran}

Strategi pembelajaran dapat diartikan sebagai setiap kegiatan yang dipilih yaitu yang dapat memberikan fasilitas atau bantuan kepada peserta didik menuju tercapainya tujuan tertentu.

Menurut Gerlach dan Ely menjelaskan bahwa strategi pembelajaran merupakan caracara yang dipilih untuk menyampaikan metode pembelajaran dalam lingkungan pembelajaran tertentu. Strategi pembelajaran meliputi sifat lingkup dan urutan kegiatan pembelajaran yang dapat memberikan pengalaman belajar kepada pserta didik (Uno, 2012, p. 2).

Menurut Suparman strategi pembelajaran merupakan perpaduan urutan kegiatan pembelajaran (tahap-tahap yang perlu dilalui/ diikuti dalam penyajian materi pembelajaran) metode atau teknik pembelajaran (prosedur teknis pengorganisasian bahan dan pengelolaan peserta didik dalam proses pembelajaran), media pembelajaran (peralatan dan bahan pembelajaran yang digunakan sebagai media proses pembelajaran), dan waktu pembelajaran (waktu yang diperlukan untuk menyelesaikan kegiatan pembelajaran) (Nasution, 2017, p. 5).

Secara umum, strategi adalah alat, rencana, atau metode yang digunakan untuk menyelesaikan suatu tugas. Dalam konteks pembelajaran, strategi berkaitan dengan pendekatan dalam penyampaian materi pada lingkungan pembelajaran. Strategi pembelajaran juga dapat diartikan sebagai pola kegiatan pembelajaran yang dipilih dan digunakan pendidik secara kontekstual, sesuai dengan karakteristik peserta didik, kondisi sekolah, lingkungan sekitar dan tujuan pembelajaran yang telah dirumuskan (Beckman, 2004, p. 1).

E. Mulyasa (Mulyasa, 2003, p. 54) dalam bukunya mengemukakan lima ciri yang harus diperhatikan dalam strategi pembelajaran yaitu:

1. Pembelajaran harus memperhatikan pengetahuan yang sudah dimiliki oleh peserta didik.

2. Pembelajaran dimulai dari keseluruhan (global) menuju bagian-bagian khusus.

3. Pembelajaran harus ditekankan pada pemahaman dengan cara:

a. Menyusun konsep sementara; 
b. Melakukan sharing untuk memperoleh masukan dan tanggapan dari orang lain;

c. Kerevisi dan mengembangkan konsep.

4. Pembelajaran ditekankan pada upaya mempraktekkan secara langsung apa-apa yang dipelajari.

5. Adanya refleksi terhadap strategi pembelajaran dan pengembangan pengetahuan yang dipelajari.

Strategi pembelajaran merupakan keseluruhan proses dan metode kegiatan pembelajaran pendidik dengan peserta didik dalam mencapai tujuan pembelajaran yang efektif dan efisien sesuai dengan urutan kegiatan, metode, media, dan waktu pembelajaran yang digunakan oleh pendidik dan peserta didik dalam kegiatan pembelajaran.

Dalam memilih strategi dalam pembelajaran diperlukan pemilihan strategi yang tepat, karena pengajaran yang diberikan kepada peserta didik bukanlah sesuatu yang bersifat paksaan dan berperilaku layaknya pemimpin pun tidak diperlukan. Artinya pendidik seharusnya lebih mengarahkan kepada bimbingan dan memberikan pengetahuan sesuai dengan kemampuan peserta didik dan memberikan dorongan motivasi agar peserta didik memiliki keinginan untuk terus belajar dan maju. Mereka memiliki kebebasan untuk maju sesuai dengan karakter dan kemampuan dibidangnya masing-masing. Oleh karena itu, tugas pendidik yaitu memilih strategi yang tepat yang sesuai dengan tujuan pembelajaran serta karakteristik peserta didik.

Untuk melaksanakan semua hal tersebut secara profesional, pendidik diharuskan memiliki wawasan yang mantap tentang strategi pembelajaran yang sesuai dengan tujuan belajar atau tujuan pembelajaran yang telah dirumuskan, baik dalam arti efek instruksional (tujuan yang telah dirumuskan secara eksplisit) maupun dalam arti efek pengiring (hasil yang didapat dalam proses pembelajaran), misalnya, kemampuan berpikir kritis, kreatif, terbuka, dan lain-lain (Ni'am, 2006, p. 3).

\section{Pemilihan Model Pembelajaran Sebagai Implementasi Strategi Pembelajaran}

Model-model pembelajaran dapat diklasifikasikan berdasarkan tujuan pembelajarannya, sintaks (pola urutannya) dan sifat lingkungan belajarnya. Sebagai contoh pengklasifikasian berdasarkan tujuan adalah pembelajaran langsung, suatu model pembelajaran yang baik untuk membantu siswa mempelajari keterampilan dasar. 
Sintaks (pola urutan) dari suatu model pembelajaran adalah pola yang menggambarkan urutan alur tahap-tahap keseluruhan yang pada umumnya disertai dengan serangkaian kegiatan pembelajaran. Sintaks (pola urutan) dari suatu model pembelajaran tertentu menunjukkan dengan jelas kegiatan-kegiatan apa yang harus dilakukan oleh guru atau siswa. Sintaks (pola urutan) dari bermacam-macam model pembelajaran memiliki komponen-komponen yang sama. Contoh, setiap model pembelajaran diawali dengan upaya menarik perhatian siswa dan memotivasi siswa agar terlibat dalam proses pembelajaran. Setiap model pembelajaran diakhiri dengan tahap menutup pelajaran, didalamnya meliputi kegiatan merangkum pokok-pokok pelajaran yang dilakukan oleh siswa dengan bimbingan guru.

Pemilihan model dan metode pembelajaran menyangkut strategi dalam pembelajaran. Strategi pembelajaran adalah perencanaan dan tindakan yang tepat dan cermat mengenai kegiatan pembelajaran agar kompetensi dasar dan indikator pembelajarannya dapat tercapai. Pembelajaran adalah upaya menciptakan iklim dan pelayanan terhadap kemampuan, potensi, minat, bakat, dan kebutuhan peserta didik yang beragam agar terjadi interaksi optimal antara guru dengan siswa serta antara siswa dengan siswa. Di madrasah, tindakan pembelajaran ini dilakukan nara sumber (guru) terhadap peserta didiknya (siswa). Jadi, pada prinsipnya strategi pembelajaran sangat terkait dengan pemilihan model dan metode pembelajaran yang dilakukan guru dalam menyampaikan materi bahan ajar kepada para siswanya.

Pada saat ini banyak dikembangkan model-model pembelajaran. Menurut penemunya, model pembelajaran temuannya tersebut dipandang paling tepat diantara model pembelajaran yang lain. Untuk menyikapi hal tersebut diatas, maka perlu kita sepakati hal-hal sebagai berikut :

1. Siswa Pendidikan Dasar atau Madrasah Ibtidaiyah banyak yang masih berada dalam tahap berpikir konkret. Model dan metode apapun yang diterapkan, pemanfaatan alat peraga masih diperlukan dalam menjelaskan beberapa konsep pembelajaran.

2. Kita tidak perlu mendewakan salah satu model pembelajaran yang ada. Setiap model pembelajaran pasti memiliki kelemahan dan kekuatan. 
3. Kita dapat memilih salah satu model pembelajaran yang kita anggap sesuai dengan materi pembelajaran kita; dan jika perlu kita dapat menggabungkan beberapa model pembelajaran.

4. Model apa pun yang kita terapkan, jika kita kurang menguasai meteri dan tidak disenangi para siswa, maka hasil pembelajaran menjadi tidak efektif.

5. Oleh kerena itu komitmen kita adalah sebagai berikut :

a. Kita perlu menguasai materi yang harus kita ajarkan, dapat mengajarkannya, dan terampil dalam menggunakan alat peraga.

b. Kita berniat untuk memberikan yang kita punyai kepada para siswa dengan sepenuh hati, hangat, ramah, antusias, dan bertanggung jawab.

c. Menjaga agar para siswa "mencintai" kita, menyenangi materi yang kta ajarkan, dengan tetap menjaga kredibilitas dan wibawa kita sebagai guru dapat mengembangkan model pembelajaran sendiri. Anggaplah kita sedang melaksanakan Penelitian Tindakan Kelas.

Dalam pemilihan model pembelajaran diperlukan adanya strategi dalam pembelajaran itu sendiri, agar proses pembelajaran dapat berjalan dengan efektif sesuai dengan tujuan yang diharapkan. Oemar Hamalik mengemukakan tentang unsur-unsur yang harus diperhatikan dalam pembelajaran efektif. Hal tersebut dikemukakan dalam bukunya yang berjudul "Kurikulum dan Pembelajaran", adapun unsur-unsur tersebut sebagai berikut:

1. Unsur dinamis pembelajaran pada diri guru;

a. Motivasi pembelajaran peserta didik;

b. Kondisi guru siap membelajarkan peserta didik;

2. Unsur pembelajaran kongruen dengan unsur belajar;

a. Motivasi belajar menuntut sikap tanggap dari guru serta kemampuan untuk memotivasi dengan berbagai upaya;

b. Sumber yang digunakan sebagai bahan belajar terdapat di buku pelajaran, pribadi guru, dan sumber masyarakat;

c. Pengadaan alat bantu mengajar dilakukan oleh guru, peserta didik dan bantuan orangtua. 
d. Menjamin dan membina suasana belajar yang efektif;

e. Subjek belajar yang berada dalam kondisi kurang mendukung/efektif perlu diberikan binaan.

Dalam konteks pembelajaran terdapat empat unsur yang harus diperhatikan oleh para pendidik dalam melakukan proses pembelajaran, keempat unsur tersebut adalah:

1. Menetapkan spesifikasi dan kualifikasi pembelajaran yakni perubahan profil perilaku dan pribadi peserta didik.

2. Mempertimbangkan dan memilih sistem pendekatan pembelajaran yang dipandang paling efektif.

3. Mempertimbangkan dan menetapkan langkah-langkah atau prosedur, metode, dan teknik pembelajaran.

4. Menetapkan norma-norma dan batas minimum ukuran keberhasilan atau kriteria dan ukuran baku keberhasilan.

Pada awal pembelajaran semua model pembelajaran berisikan motivasi, mengalihkan perhatian siswa, menghubungkan materi pembelajaran dengan contoh kehidupan seharihari, menjelaskan dan menerangkan tujuan dari pembelajaran dan sebagainya. Kemudian pada akhir pembelajaran berisi tentang kesimpulan dari materi yang telah disampaikan, refleksi (latihan atau tanya jawab) yang dilakukan siswa sesuai dengan arahan guru. Tahapan yang paling penting terdapat pada tahapan inti dalam proses pembelajaran. Pada tahapan ini terdapat perbedaan dalam penerapannya, seperti dalam pemilihan model pembelajaran. Dalam setiap model pembelajaran diperlukan sistem pengelolaan dan lingkungan belajar yang berbeda-beda sesuai dengan materi pembelajaran yang dibahas.

Pada model pembelajaran langsung diperlukan lingkungan yang bisa mengalihkan perhatian peserta didik untuk fokus pada materi yang disampaikan. Ada beberapa macam model-model dan strategi pembelajaran yang dapat diterapkan dalam pembelajaran, diantaranya:

1. Model dan strategi pembelajaran langsung (ekspositori) merupakan strategi pembelajaran yang menekankan pada proses penyampaian materi secara verbal. Model pembelajaran ini merupakan pengembangan dari teori pembiasaan perilaku (Syah, 2000, 
p. 110). Menurut Bandura, ada 4 fase belajar dari model pembelajaran langsung, yaitu: fase perhatian, fase retensi, fase produksi, dan fase motivasi (Arend, 1997, p. 72).

Meskipun dalam strategi pembelajaran ekspositori digunakan metode selain ceramah dan dilengkapi atau didukung dengan penggunaan media, penekanannya tetap pada proses penerimaan pengetahuan (reception learning) bukan pada proses pencarian dan konstruksi pengetahuan (Rasyidin, 2015, p. 138).

2. Model dan strategi pembelajaran koperatif merupakan strategi pembelajaran dimana para peserta didik dibagi menjadi beberapa kelompok kecil yang memiliki tingkat kemampuan yang berbeda-beda, kemudian mereka diminta untuk bekerja sama dalam menyelesaikan tugas kelompok.

3. Model dan strategi pembelajaran inkuiri merupakan strategi untuk mengembangkan kemampuan peserta didik dan merefleksikannya dalam kehidupan sosial, melatih untuk mandiridalam masyarakat.

4. Model dan strategi pembelajaran bermain peran (Role Playing) merupakan strategi pembelajaran yang berhubungan dengan peristiwa-peristiwa sejarah, geografi dan ekonomi.

5. Model dan strategi pembelajaran berbasis masalah dengan fokus pemecahan masalah (Problem Based Learning) merupakan strategi untuk melatih peserta didik fokus terhadap pemecahan masalah yang nyata dan didorong untuk lebih aktif terlibat dalam materi pelajaran dan keterampilan berpikir kritis.

\section{PENUTUP}

Proses pembelajaran pada umumnya berlangsung secara satu arah yang kita kenal dengan Transfer Knowledge (Pengalihan Pengetahuan), nilai-nilai, informasi dan lainnya yang bersumber dari pendidik (guru) kepada peserta didik. Peserta didik merupakan manusia yang memiliki pengetahuan, pengalaman, keterampilan, cita-cita dan kesenangan, oleh karena itu perlunya kemampuan yang mereka miliki harus kita hargai dalam proses pembelajaran. Tentunya perlu adanya implikasi strategi pembelajaran yang efektif, interaktif baik antara pendidik dengan peserta didik. 
Dengan begitu, pemilihan model dan strategi pembelajaran yang tepat akan dapat membina peserta didik ntuk dapat berpikir kreatif, mandiri dan adaptif terhadap berbagai situasi yang terjadi dang mungkin akan terjadi. Pendidik memikirkan dan mempersiapkan model dan strategi pembelajaran yang tepat agar peserta didik mampu menerima dan memproses informasi yang disampaikan oleh pendidik.

\section{DAFTAR PUSTAKA}

Beckman, K.B Ames. 2004. The Free Radical Theory of Aging Matures, Physiological Reviews. Hamruni. 2011. Strategi Pembelajaran, Yogyakarta: Insan Madani.

Ismail. 2003. Model-Model Pemelajaran. Jakarta: Direktorat Pendidikan Lanjutan Pertama Depdiknas.

Miarso , Yusufhadi. 2005. Menyemai Benih Teknologi Pendidikan. Jakarta: Prenada Media Group.

Muchtar , Al, Suwarma, dkk. 2007. Strategi Pembelajaran PKN. Jakarta: UT.

Mulyasa, E. 2003. Kurikulum Berbasis Kompetens;Konsep,Karakteristik dan Implementasi.

Bandung: PT Remaja Rosda Karya.

Nasution, Wahyudin Nur. 2017. Strategi Pembelajaran. Medan: Perdana Publishing.

Ni'am, M. Asrorun. Membangun Profesionalitas Guru. Jakarta: Elsas.

R.I, Arend. 1997. Classroom Instruction and Management,. New York: McGraw Hill Companies.

Rasyidin, Al dan Wahyudin Nur Nasution. 2015. Teori Belajar dan Pembelajaran. Medan: Perdana Publishing.

Syah, Muhibbin. Psikologi Pendidikan dengan Pendekatan Baru. Bandung: Remaja Rosdakarya.

Uno, Hamzah B, dkk. 2012. Model Pembelajaran, Gorontalo: BMT Nurul Jannah. 